\title{
Effect of using insect larvae meal as a complete protein source on quality and productivity characteristics of laying hens
}

\author{
Mohammed Farooq Abdulhameed Al-Qazzaz' ${ }^{1}$, Dahlan Ismail ${ }^{1}$, Henny Akit ${ }^{1}$, \\ Lokman Hakim Idris ${ }^{1}$
}

${ }^{1}$ University Putra Malaysia, Serdang, Selangor, Malaysia.

ABSTRACT - This study was conducted to evaluate the effect of black soldier fly larvae (BSFL) as a source of protein in layer diets on product performance, egg quality, hatchability, fertility, and sensory characteristics of eggs. The BSFL contained a high percentage of protein (559.9 $\left.\mathrm{g} \mathrm{kg}^{-1}\right)$, metabolizable energy $\left(696.3 \mathrm{kcal} \mathrm{kg}^{-1}\right)$, crude fat $\left(18.6 \mathrm{~g} \mathrm{~kg}^{-1}\right)$, and dry matter $\left(178 \mathrm{~g} \mathrm{~kg}^{-1}\right)$ and a good balance of amino acids. A total of 54 Arabic strain hens at nine months of age were mixed with nine cocks at 12 months old; all were divided into three treatments. The diets were formulated based on three levels of energy-toprotein ratio: 155,140 , and 170 . The BSFL meal was added at 0,50 , and $10 \mathrm{~g} \mathrm{~kg}^{-1}$ respectively. The results showed that feed intake, weight gain, Haugh unit, and hatchability were not affected by dietary treatments with BSFL. However, there was significant improvement in hen day egg production and hen house egg production due to dietary treatments of BSFL. Also, feed conversion ratio, egg weight, shell thickness, shell weight, egg yolk color, fertility, and egg mass were affected by dietary treatments. In addition, a significant improvement was observed in appearance, texture, taste, and acceptance of eggs of hens fed BSFL at $50 \mathrm{~g} \mathrm{~kg}^{-1}$. The odor was not affected by dietary treatments. Black soldier fly larvae can be a good source of protein in layer diets.

Key Words: black soldier fly larvae, energy to protein ratio, laying hen

\section{Introduction}

Feed cost can form up to $70 \%$ of the total cost of poultry production. Animal protein sources are preferred over plant protein sources because animal proteins contain a good balance of essential amino acids and an excellent content of vitamins (Saima et al., 2008). Fish meal is a high-quality protein source used mainly in poultry diets. However, the high price of fish meal has led to a search for alternative protein sources.

Insects are natural food sources for poultry, and they are considered a fundamental protein source for poultry in the wild. Insects contain a good amount of protein, which can be as high as $64 \%$ (Hwangbo et al., 2009) to as low as $39.16 \%$ (Atteh and Ologbenla, 2015), with a high balance of essential amino acids. Many insects have been used in poultry feed, such as grasshoppers (Hassan et al., 2009), house flies (Hwangbo et al., 2009), and mealworms (RamosElorduy et al., 2002). Black soldier fly larvae (Hermetia

Received April 4, 2016 and accepted May 18, 2016.

Corresponding author: mohfa77@hotmail.com

http://dx.doi.org/10.1590/\$1806-92902016000900003

Copyright $\odot 2016$ Sociedade Brasileira de Zootecnia. This is an Open Access article distributed under the terms of the Creative Commons Attribution License (http://creativecommons.org/licenses/by/4.0/), which permits unrestricted use, distribution, and reproduction in any medium, provided the original work is properly cited. illucens Linnaeus) have been found to be abundant in most areas of Malaysia. They are called latrine larvae because they can be found around the manure piles of cattle, sheep, and poultry (Van Huis, 2013). Black soldier flies are not found in human foods or habitats because they do not have functional mouth parts. Black soldier fly larvae (BSFL) have been used to solve some environmental problems related to manure and other organic wastes, such as decreasing manure mass, moisture content, and offensive odors (Barry, 2004; Newton et al., 2005). In addition, they have been used to produce high-value feedstuff for cattle, pigs, poultry, and fish (Newton et al., 2005). The proximate composition of BSFL is variable according to the processing method (Aniebo and Owen, 2010).

The objective of this study was to evaluate the effect of BSFL as a protein source in layer diets on growth performance, egg quality, fertility, hatchability, and sensory characteristics of eggs.

\section{Material and Methods}

This research was conducted in Serdang, Selangor, Malaysia. A total of 54 village chickens of Arabian strain at nine months old were used, standardized according to physical characteristics, weight, and health aspects. Hens were housed in nine floor cages $(200 \mathrm{~cm} \times 300 \mathrm{~cm})$, at six 
hens per cage. Three treatments and three replications of six birds were assigned to the completely randomized design. Nine cocks of Arabian strain at 12 months of age were mixed with the hens (one cock per replicate). The treatments consisted of a basal diet (Table 1) supplemented with BSFL at $50 \mathrm{~g} \mathrm{~kg}^{-1}$ and $10 \mathrm{~g} \mathrm{~kg}^{-1}$. The diets were formulated based on the energy-to-protein ratio. The energy-to-protein ratios were 155 (2777.16 kcal/kg energy, $178.6 \mathrm{~g} \mathrm{~kg}^{-1}$ protein), 140 (2668.93 kcal/kg, $190.5 \mathrm{~g} \mathrm{~kg}^{-1}$ protein), and 170 (2836.14 kcal $/ \mathrm{kg}, 166.4 \mathrm{~g} \mathrm{~kg}^{-1}$ protein). Protein sources were used $\left(50 \mathrm{~g} \mathrm{~kg}^{-1} \mathrm{BSFL}\right.$ and $40 \mathrm{~g} \mathrm{~kg}^{-1}$ meat and bone meal) to achieve the energy-to-protein ratio of 140. Amino acids (methionine and lysine) were added to achieve the requirement of the diet formulation due to using $10 \mathrm{~g} \mathrm{~kg}^{-1}$ BSFL. Hens with cocks were supplied $80 \mathrm{~g} /$ day of feed, and they were allowed ad libitum access to water.

Live BSFL less than one week old were processed by being dried at $60{ }^{\circ} \mathrm{C}$ for five days and then ground. Black soldier fly larvae meal was used as a source of protein in layer diets.

Fresh food waste was collected daily from restaurants in Serdang. It was separated into rice as a source of energy and meat with bone meal as a source of protein. Food waste was processed by being washed, soaked in hot water at $90{ }^{\circ} \mathrm{C}$ for $10 \mathrm{~min}$, dried in an oven at $60^{\circ} \mathrm{C}$ for two days, and then ground (Hossein and Dahlan, 2015).

Samples of BSFL meal and food waste were analyzed for the proximate composition according to AOAC (2005). Amino acid analysis of BSFL was conducted by reversedphase high-performance liquid chromatography (RP-HPLC)

Table 1 - Ingredient composition of the experimental diets

\begin{tabular}{lccc}
\hline Ingredient & $\begin{array}{c}\text { Control } \\
\left(\mathrm{g} \mathrm{kg}^{-1}\right)\end{array}$ & $\begin{array}{c}5 \% \text { BSFL } \\
\left(\mathrm{g} \mathrm{kg}^{-1}\right)\end{array}$ & $\begin{array}{c}1 \% \text { BSFL } \\
\left(\mathrm{g} \mathrm{kg}^{-1}\right)\end{array}$ \\
\hline Rice bran & 140 & 103.5 & 48 \\
Fish meal & 30 & 0 & 0 \\
Corn & 202 & 200 & 265 \\
Meat and bone waste & 40 & 40 & 60 \\
Rice waste & 300 & 310 & 350 \\
Limestone & 90 & 90 & 85 \\
Di calcium phosphate & 5 & 9.5 & 5 \\
Soybean & 185 & 190.5 & 170 \\
BSFL meal & 0 & 50 & 10 \\
Sodium chloride & 5 & 3 & 3 \\
Methionine & 2 & 2 & 2 \\
Lysine & 1 & 1.5 & 2 \\
Calculated analysis & & & \\
Crude protein $\left(\mathrm{g} \mathrm{kg}^{-1}\right)$ & 178.6 & 190.5 & 166.4 \\
Metabolizable energy $\left(\mathrm{kcal} \mathrm{kg}^{-1}\right)$ & 2777.16 & 2668.93 & 2836.14 \\
E/P ratio & 155.49 & 140.03 & 170.35 \\
Phosphorus $\left(\mathrm{g} \mathrm{kg}^{-1}\right)$ & 4 & 4 & 4 \\
Calcium $\left(\mathrm{g} \mathrm{kg}^{-1}\right)$ & 40 & 40 & 40 \\
Linoleic acid $\left(\mathrm{g} \mathrm{kg}^{-1}\right)$ & 25.8 & 28.8 & 27.9 \\
\hline BSFL - b s ser & & &
\end{tabular}

BSFL - black soldier fly larvae; E/P - energy/protein ratio.
(Rozan et al., 2000). The metabolizable energy of BSFL and food waste was determined according to the method of NRC (1994). The number of eggs laid by hens in each replicate was recorded daily. The hen daily egg production (HDEP) and hen house egg production (HHEP) were calculated by adopting the following formulae given by NRC (1994):

$$
\begin{gathered}
\text { HDEP }=\frac{\text { Number of eggs produced on daily basis }}{\text { Number of birds available in the flock on that day }} \times 100 \\
\text { HHEP }=\frac{\text { Total number of eggs produced by flock }}{\text { Total number of hens housed }} \times 100
\end{gathered}
$$

Eggs produced by each replicate were weighed daily using an electronic weighing scale, and the average was recorded. All eggs were stored in the refrigerator $\left(5^{\circ} \mathrm{C}\right)$ for $24 \mathrm{~h}$ before determining egg quality characteristics. Haugh unit and yolk color were measured using an egg analyzer (Orka Food Technology) after one week from the start of the experiment period and at the end of every month. Feed conversion ratio ( $\mathrm{kg}$ diet $/ \mathrm{kg}$ egg) data were reported every four weeks. The initial body weight for each replicate was recorded at the beginning of the experiment, and then the hens were weighed at the end of each month to record changes in body weight. Eggshells were dried at $60{ }^{\circ} \mathrm{C}$ for $24 \mathrm{~h}$ and then weighed on an electronic scale. Eggshell thickness was measured using a digital caliper. Incubating eggs of treatments were collected for five days and stored at $5{ }^{\circ} \mathrm{C}$ then placed in the incubator at the end of each month. After hatching, hatched chicks were collected and counted to determine hatchability in relation to the number of fertile eggs (North, 1984).

The egg sensory evaluation was carried out by an untrained panel consisting of 30 judges aged between 20 and 35 years. Panel judges were instructed in the process of evaluating the parameters appearance, odor, texture, taste, and acceptance of the sensory quality of eggs. The parameters were quantified by a nine-point hedonic scale $(1=$ dislike extremely; $9=$ like extremely). Thirty eggs from each treatment were boiled for $10 \mathrm{~min}$ and left to cool at room temperature. The eggs were peeled and cut into quarters in white plate. The panelists were placed in the conditioned room, alone, so as not to interfere with the outcome of the others. Sensory evaluation was carried out after breakfast so that the sensation of hunger would not interfere with the result.

The experimental design was completely randomized, and the data were analyzed by using the general linear models of SAS (Statistical Analysis System, version 9.3) software. The differences between means were compared 
using Duncan's New Multiple Range Test (Duncan, 1955) on SAS (Statistical Analysis System, version 9.3) software.

\section{Results and Discussion}

The BSFL meal had a high protein content $\left(559.9 \mathrm{~g} \mathrm{~kg}^{-1}\right)$ and low amounts of crude fat $\left(18.6 \mathrm{~g} \mathrm{~kg}^{-1}\right)$ and dry matter $\left(178 \mathrm{~g} \mathrm{~kg}^{-1}\right)$ (Table 2). The BSFL contained good quantity and quality of amino acids, especially the essential amino acids methionine (26.4 $\left.\mathrm{g} \mathrm{kg}^{-1}\right)$ and lysine $\left(28.6 \mathrm{~g} \mathrm{~kg}^{-1}\right)$ (Table 3). Thus, BSFL could be a good protein source in poultry diets. Fat content was very low in the BSFL meal; thus, it can be stored for a long time. The protein and fat contents of the BSFL in this study did not fall under the ranges reported by previous researchers, who have reported 40-42\% protein and 30-35\% fat (Arango Gutiérrez et al., 2004; Sheppard et al., 1994; St-Hilaire et al., 2007). This could be because the BSFL used in this study were less than one week old and because of the use of an oven-drying method. Aniebo and Owen (2010) reported an increase in protein content and a decrease in fat content in oven-dried maggot meal compared with sun-dried maggot meal. Also,

Table 2 - Proximate composition of BSFL

\begin{tabular}{lc}
\hline Component & Nutrient composition \\
\hline Dry matter $\left(\mathrm{g} \mathrm{kg}^{-1}\right)$ & $178 \pm 0.35$ \\
Crude protein $\left(\mathrm{g} \mathrm{kg}^{-1}\right)$ & $559.9 \pm 0.85$ \\
Crude fat $\left(\mathrm{g} \mathrm{kg}^{-1}\right)$ & $18.6 \pm 0.24$ \\
$\mathrm{Ash}\left(\mathrm{g} \mathrm{kg}^{-1}\right)$ & $8.1 \pm 0.009$ \\
$\mathrm{Ca}\left(\mathrm{mg} \mathrm{g}^{-1}\right)$ & $0.038 \pm 0.005$ \\
$\mathrm{P}\left(\mathrm{mg} \mathrm{g}^{-1}\right)$ & $0.079 \pm 0.012$ \\
Metabolizable energy $\left(\mathrm{kcal} \mathrm{kg}^{-1}\right)$ & $696.3426 \pm 23.7$ \\
\hline
\end{tabular}

BSFL - black soldier fly larvae.

Values $=$ means \pm standard deviation

Table 3 - Amino acid of composition of black soldier fly larvae

\begin{tabular}{lc}
\hline Amino acid & $\left(\mathrm{g} \mathrm{kg}^{-1}\right)$ \\
\hline Aspartic acid & 48.08 \\
Glutamic acid & 65.81 \\
Serine & 32.88 \\
Glycine & 10.9 \\
Histidine & 14.76 \\
Arginine & 93.31 \\
Threonine & 22.36 \\
Alanine & 52.45 \\
Proline & 36.65 \\
Tyrosine & 26.97 \\
Valine & 21.93 \\
Methionine & 26.46 \\
Cysteine & 89.17 \\
Isoleucine & 12.22 \\
Leucine & 37.33 \\
Phenylalanine & 16.29 \\
Tryptophan & 0.49 \\
Lysine & 28.63 \\
\hline
\end{tabular}

they found that house fly larvae that had been harvested at two days of age had a higher protein content and lower fat content than that those harvested at four days of age. Ash content was relatively low $\left(8.1 \mathrm{~g} \mathrm{~kg}^{-1}\right)$ in the BSFL meal. This could be due to the mineral content in BSFL meal being low at this age.

High protein content $\left(441.8 \mathrm{~g} \mathrm{~kg}^{-1}\right)$ and metabolizable energy $(3789 \mathrm{kcal} / \mathrm{kg}$ ) were reported in the meat and bone waste (Table 4). Protein content was $89.5 \mathrm{~g} \mathrm{~kg}^{-1}$, and metabolic energy was $3402 \mathrm{kcal} / \mathrm{kg}$ in the rice waste. Feed values of food waste vary depending upon the source of the waste. Kwak et al. (2002) reported that restaurant food waste has a higher nutritional value than apartment food waste.

Productive characteristics such as HDEP, HHEP, egg mass, egg weight, and feed conversion ratio were influenced by dietary treatments with BSFL (Table 5). The significantly $(\mathrm{P}<0.001)$ highest hen day egg production was in the diet of hens fed BSFL at $50 \mathrm{~g} \mathrm{~kg}^{-1}$. A similar result was found in HHEP, with a significant $(\mathrm{P}<0.05)$ increase in HHEP in the diet of hens fed BSFL at $50 \mathrm{~g} \mathrm{~kg}^{-1}$ compared with those fed BSFL at 0 and $10 \mathrm{~g} \mathrm{~kg}^{-1}$. There were no significant differences in egg mass between hens fed BSFL at $50 \mathrm{~g} \mathrm{~kg}^{-1}$ and hens fed the control diet. However, a significant decrease $(\mathrm{P}<0.001)$ was observed in egg mass of hens fed BSFL at $10 \mathrm{~g} \mathrm{~kg}^{-1}$ compared with those fed BSFL at $50 \mathrm{~g} \mathrm{~kg}^{-1}$ and the control diet. The significant improvement in egg production of hens fed BSFL at $50 \mathrm{~g} \mathrm{~kg}^{-1}$ could be because the diet was formulated with a high protein content and lower energy level in this treatment, which met the requirements of hens for maintenance and production. Also, this could be a result of the complementary effect of the amino acid profile of the BSFL meal. According to Widjastuti et al. (2014), increased levels of BSFL meal in quail diets had no effect on egg production.

Table 4 - Centesimal composition of food waste

\begin{tabular}{lc}
\hline & Nutrient composition \\
\hline Meat and bone waste & \\
Crude protein $\left(\mathrm{g} \mathrm{kg}^{-1}\right)$ & $441.8 \pm 2.37$ \\
Crude fat $\left(\mathrm{g} \mathrm{kg}^{-1}\right)$ & $217.8 \pm 1.06$ \\
Dry matter $\left(\mathrm{g} \mathrm{kg}^{-1}\right)$ & $953.8 \pm 0.28$ \\
Ash $\left(\mathrm{g} \mathrm{kg}^{-1}\right)$ & $164.9 \pm 0.15$ \\
Metabolizable energy $\left(\mathrm{kcal} \mathrm{kg}^{-1}\right)$ & $3789.42 \pm 0.86$ \\
Rice & \\
Crude protein $\left(\mathrm{g} \mathrm{kg}^{-1}\right)$ & $89.5 \pm 1.89$ \\
Crude fat $\left(\mathrm{g} \mathrm{kg}^{-1}\right)$ & $33.8 \pm 0.21$ \\
Dry matter $\left(\mathrm{g} \mathrm{kg}^{-1}\right)$ & $924.8 \pm 0.24$ \\
Ash $\left(\mathrm{g} \mathrm{kg}^{-1}\right)$ & $58.5 \pm 3.5$ \\
Crude fiber $\left(\mathrm{g} \mathrm{kg}^{-1}\right)$ & $14.4 \pm 0.44$ \\
Metabolizable energy $\left(\mathrm{kcal} \mathrm{kg}^{-1}\right)$ & $3402 \pm 0.70$ \\
\hline
\end{tabular}

Values $=$ mean \pm standard deviation. 
Table 5 - Effect of dietary treatments of BSFL on performance of hens

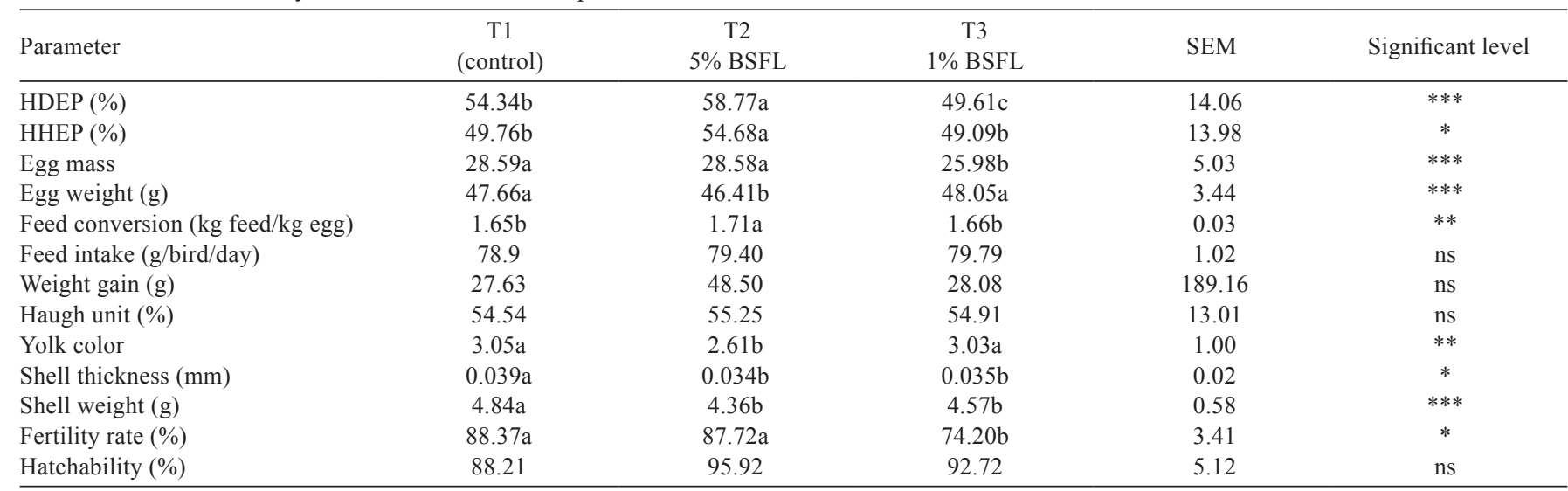

a,b,c - means within rows with different letters are significantly different.

${ }^{*} \mathrm{P}<0.05 ; * * \mathrm{P}<0.01 ; * * * \mathrm{P}<0.001 ; \mathrm{ns}-$ means within the same column with no letters are not significantly different.

BSFL - black soldier fly larvae; SEM - standard error of the mean; HDEP - hen daily egg production; HHEP - hen house egg production.

The egg weight was significantly $(\mathrm{P}<0.001)$ lower in hens fed BSFL at $50 \mathrm{~g} \mathrm{~kg}^{-1}$ compared with those fed the basal diet and BSFL at $10 \mathrm{~g} \mathrm{~kg}^{-1}$. This could be because the energy level in the diet utilization of hens fed the BSFL at $50 \mathrm{~g} \mathrm{~kg}^{-1}$ was lower than in the diet utilization of hens fed the basal diet and those fed BSFL at $10 \mathrm{~g} \mathrm{~kg}^{-1}$. With energy levels decreasing from 2800 to $2700 \mathrm{kcal} \mathrm{kg}^{-1}$, egg weight decreased from 47.66 to $46.41 \mathrm{~g}$. This result agreed with Wu et al. (2005). Sohail et al. (2003) reported that increasing dietary energy had positive effects on egg weight.

Feed conversion ratio was significantly $(\mathrm{P}<0.01)$ higher with inclusion of BSFL in the layer diet. The increase in feed conversion ratio was an indication of poor feed utilization, which could be due to the effect of chitin. Amao et al. (2010) reported that replacement of fish meal with larvae meal by $100 \mathrm{~g} / 100 \mathrm{~g}$ led to a significant increase in the feed conversion ratio of laying hens. Feed intake and weight gain were not influenced by dietary treatments of BSFL.

Egg yolk color was affected by dietary treatments; the egg yolk color of eggs laid by hens fed BSFL at $50 \mathrm{~g} \mathrm{~kg}^{-1}$ was significantly brighter than those fed the basal diet and BSFL at $10 \mathrm{~g} \mathrm{~kg}^{-1}$. This indicates that the hens fed BSFL were not able to use the color pigments in yolk formation. Also, this could be due to the fact that BSFL are not a vegetable product, which could contain carotene or xanthophyllous pigments needed for egg coloration development. A similar result was observed by Akpodiete et al. (1998), who found that yolk color was significantly decreased by replacement of fish meal with maggot meal in the laying chicken diet. The Haugh unit was not significantly affected by dietary treatments.
Shell thickness $(\mathrm{P}<0.05)$ and shell weight $(\mathrm{P}<0.001)$ were significantly affected by dietary treatment of BSFL. Hens fed $100 \%$ fish meal gave the highest thickness and shell weight values. The shell thickness and shell weight were significantly decreased with increasing levels of BSFL in the diet. This could be due to the calcium content in BSFL meal being lower than that of fish meal. Agunbiade et al. (2007) reported a decrease in shell thickness and shell weight with increasing levels of BSFL in the layer diet.

Hatchability was not significantly influenced by the dietary treatments with BSFL. There were no significant differences in fertility rate between hens fed BSFL at $50 \mathrm{~g} \mathrm{~kg}^{-1}$ and hens fed the basal diet. However, the fertility rate was significantly decreased in hens fed BSFL at $10 \mathrm{~g} \mathrm{~kg}^{-1}$ compared with those fed BSFL at $50 \mathrm{~g} \mathrm{~kg}^{-1}$ and the control diet. This result was not in agreement with Ernst et al. (1984), who found increased hatchability of laying hens fed maggot meal.

Appearance, texture, taste, and acceptance were significantly affected by dietary treatments with BSFL (Table 6). Increasing levels of BSFL significantly improved $(\mathrm{P}<0.001)$ the appearance, texture, and taste of eggs $(\mathrm{P}<0.01)$. Also, the acceptance of eggs was significantly $(\mathrm{P}<0.05)$ improved by increasing levels of BSFL in the diet. The significant improvement observed in the taste of eggs produced by hens fed BSFL could be due to the glutamic acid content being high in BSFL meal $\left(6.85 \mathrm{~g} \mathrm{~kg}^{-1}\right)$. Yoshida (1998) reported interactions between glutamic acid and human perception. Jaturasitha et al. (2008) reported that palatability was affected by the diet. The results indicated that there were no significant differences in egg odor between BSFL treatments. 
Table 6 - Effect of dietary treatments of BSFL on sensory evaluation of eggs

\begin{tabular}{lccccc}
\hline Characteristic & $\begin{array}{c}\mathrm{T} 1 \\
\text { (control) }\end{array}$ & $\begin{array}{c}\text { T2 } \\
\text { 5\% BSFL }\end{array}$ & $\begin{array}{c}\text { T3 } \\
\text { 1\% BSFL }\end{array}$ & SEM & $\begin{array}{c}\text { Significant } \\
\text { level }\end{array}$ \\
\hline Appearance & $6.63 \mathrm{~b}$ & $7.36 \mathrm{a}$ & $7.18 \mathrm{a}$ & 0.46 & $* * *$ \\
Odor & 6.77 & 6.81 & 6.81 & 0.59 & $\mathrm{~ns}$ \\
Texture & $6.54 \mathrm{~b}$ & $7.31 \mathrm{a}$ & $7.00 \mathrm{a}$ & 0.56 & $* * *$ \\
Taste & $6.36 \mathrm{c}$ & $7.09 \mathrm{a}$ & $6.72 \mathrm{~b}$ & 0.55 & $* *$ \\
Acceptance & $6.90 \mathrm{~b}$ & $7.23 \mathrm{a}$ & $7.00 \mathrm{ab}$ & 0.4 & $*$ \\
\hline
\end{tabular}

a,b,c - means within rows with different letters are significantly different. BSFL - black soldier fly larvae; SEM - standard error of the mean.

${ }^{*} \mathrm{P}<0.05 ; * * \mathrm{P}<0.01 ; * * * \mathrm{P}<0.001$; ns - means within the same column with no letters are not significantly different.

\section{Conclusions}

Black soldier fly larvae meal can be a good source of protein in layer diets.

\section{Acknowledgments}

This research was sponsored by Fundamental Research Grant Scheme (FRGS) of the Malaysian Ministry of Education. The authors express their appreciation and gratitude to Mr. Hairulnizam and all the technicians at Farm2, Department of Animal Science, UPM, for the technical support given during the development of the research work.

\section{References}

Agunbiade, J. A.; Adeyemi, O. A.; Ashiru, O. M.; Awojobi, H. A.; Taiwo, A. A.; Oke, D. B. and Adekunmisi, A. A. 2007. Replacement of fish meal with maggot meal in cassava-based layers' diets. The Journal of Poultry Science 44:278-282.

Akpodiete, O.; Ologhobo, A. and Onifade, A. 1998. Maggot meal as a substitute for fish meal in laying chicken diet. Ghana Journal of Agricultural Science 31:137-142

Amao, O.; Oladunjoye, I.; Togun, V.; Olubajo, K. and Oyaniyi, O. 2010. Effect of Westwood (Cirina forda) larva meal on the laying performance and egg characteristics of laying hen in a tropical environment. International Journal of Poultry Science 9:450-454

Aniebo, A. O. and Owen, O. J. 2010. Effects of age and method of drying on the proximate composition of housefly larvae (Musca domestica Linnaeus) meal (HFLM). Pakistan Journal of Nutrition 9:485-487

AOAC - Association of Official Analytical Chemistry. 2005. Official methods of analysis. AOAC International, Arlington, VA.

Arango Gutiérrez, G. P.; Vergara Ruiz, R. A. and Mejía Vélez, H. 2004. Compositional, microbiological and protein digestibility analysis of the larva meal of Hermetia illuscens L. (Diptera: Stratiomyiidae) at Angelópolis-Antioquia, Colombia. Revista Facultad Nacional de Agronomía, Medellín, 57:2491-2500.

Atteh, J. and Ologbenla, F. 2015. Replacement of fish meal with maggots in broiler diets: effects on performance and nutrient retention. Nigerian Journal of Animal Production 20:44-49.
Barry, T. 2004. Evaluation of the economic, social, and biological feasibility of bioconverting food wastes with the black soldier fly (Hermetia illucens). Thesis (D.Sc.). University of North Texas, Texas, USA.

Duncan, D. B. 1955. Multiple range and multiple F tests. Biometrics $11: 1-42$.

Ernst, L.; Vagapov, R.; Pozdeeva, E.; Zhemchina, A. and Zvereva, E. 1984. A high protein feed from poultry manure. Nutrition Abstracts and Reviews 54:445.

Hassan, A.; Sani, I.; Maiangwa, M. and Rahman, S. 2009. The effect of replacing graded levels of fishmeal with grasshopper meal in broiler starter diet. Journal Production Agriculture and Technology 5:30-38.

Hossein, S. and Dahlan, I. 2015. Growth performance of free-range village chickens fed dehydrated processed food waste. Malaysian Journal of Animal Science 18:77-86.

Hwangbo, J.; Hong, E. C.; Jang, A.; Kang, H. K.; Oh, J. S.; Kim, B. W. and Park, B. S. 2009. Utilization of house fly-maggots, a feed supplement in the production of broiler chickens. Journal of Environmental Biology 30:609-614.

Jaturasitha, S.; Srikanchai, T.; Kreuzer, M. and Wicke, M. 2008. Differences in carcass and meat characteristics between chicken indigenous to northern Thailand (Black-boned and Thai native) and imported extensive breeds (Bresse and Rhode Island Red). Poultry Science 87:160-169.

Kwak, W.; Kang, J. and Chung, J. 2002. Evaluation of nutritional characteristics of different sources of food residues in autumn and comparisons with NRC nutrient requirements for swine. Journal of Animal Environmental Science 8:87-98.

Newton, G. L.; Sheppard, D. C.; Watson, D. W.; Burtle, G. J.; Dove, C. R.; Tomberlin, J. K. and Thelen, E. E. 2005. The black soldier fly Hermetia illucens as a manure management resource recovery tool. In: Proceeding of Symposium on the State of the Science of Animal Manure and Waste Management, San Antonio, TX, USA.

North, M. O. 1984. Commercial chicken production manual. AVI publishing company. Westport, Connecticut, USA

NRC - National Research Council. 1994. Nutrient requirements of poultry. National Academy Press, Washington, D.C.

Ramos-Elorduy, J.; González, E. A.; Hernández, A. R. and Pino, J. M. 2002. Use of Tenebrio molitor (Coleoptera: Tenebrionidae) to recycle organic wastes and as feed for broiler chickens. Journal of Economic Entomology 95:214-220.

Rozan, P.; Kuo, Y.-H. and Lambein, F. 2000. Free amino acids present in commercially available seedlings sold for human consumption. A potential hazard for consumers. Journal of Agricultural and Food Chemistry 48:716-723.

Saima, M. A.; Khan, M.; Anjum, M.; Ahmed, S.; Rizwan, M. and Ijaz, M. 2008. Investigation on the availability of amino acids from different animal protein sources in golden cockerels. Journal of Animal and Plant Sciences 18:53-56.

Sheppard, D. C.; Newton, G. L.; Thompson, S. A. and Savage, S. 1994. A value added manure management system using the black soldier fly. Bioresource Technology 50:275-279.

Sohail, S.; Bryant, M. and Roland, D. 2003. Influence of dietary fat on economic returns of commercial Leghorns. The Journal of Applied Poultry Research 12:356-361.

St-Hilaire, S.; Sheppard, C.; Tomberlin, J. K.; Irving, S.; Newton, L.; McGuire, M. A.; Mosley, E. E.; Hardy, R. W. and Sealey, W. 2007. Fly prepupae as a feedstuff for rainbow trout, Oncorhynchus mykiss. Journal of the World Aquaculture Society 38:59-67.

Van Huis, A. 2013. Potential of insects as food and feed in assuring food security. Annual Review of Entomology 58:563-583. 
Widjastuti, T.; Wiradimadja, R. and Rusmana, D. 2014. The effect of substitution of fish meal by black soldier fly (Hermetia illucens) maggot meal in the diet on production performance of quail (Coturnix coturnix japonica). Scientific Papers: Series D, Animal Science 42:125-129.
Wu, G.; Bryant, M.; Voitle, R. and Roland, D. 2005. Effect of dietary energy on performance and egg composition of Bovans White and Dekalb White hens during phase I. Poultry Science 84:1610-1615.

Yoshida, Y. 1998. Umami taste and traditional seasonings. Food Reviews International 14:213-246. 